\title{
39. COMMISSION POUR LA CREATION D'OBSERVATOIRES INTERNATIONAUX
}

\author{
Président: M. H. Shapley, Director of the Harvard College Observatory, Cambridge, \\ Mass., U.S.A. \\ Membres: MM. Baade, J. G. Baker, Bowen, Gaviola, Spencer Jones, Lindblad, Lyot, \\ Oort, Redman, G. A. Shajn, Struve, Waldmeier, Witkowski.
}

At this time (March I5, I948), it is possible to make only a preliminary report on the development of the project of International Astronomical Observatories. Excellent discussions of the proposals, in response to an outline by the President of the Commission, have been received from Dr Ira Bowen and Dr Walter Baade (of Mount Wilson and Palomar); Sir Harold Spencer Jones (Greenwich); Dr R. O. Redman (Cambridge, England); Dr Otto Struve (Yerkes and McDonald); Dr Bertil Lindblad (Stockholm); Dr Enrique Gaviola (Córdoba); Dr M. Waldmeier (Zürich); Dr G. A. Shajn (Simeis); Dr Joseph Witkowski (Poznan); Dr B. Lyot (Paris). At my request Dr J. S. Paraskevopoulos, Superintendent of the Harvard South African Station, has reported on South African sites. All these reports should eventually be printed or at least fully summarized and mimeographed for the use of the International Astronomical Union. Of special value are Lyot's consideration of atmospheric conditions; the arguments of Bowen, Baade, Spencer Jones, and others in favour of a modest beginning with provision for growth when needs and directions are clearer, and Witkowski's reconsideration of our earlier plan for an International Observatory and Laboratories in southern Europe.

There is very general agreement on the following points: (I) Any new international observatory equipped with large telescopes should not be in the northern hemisphere, but preferably should be located between $10^{\circ}$ and $40^{\circ}$ southern latitude. (2) The problem of choosing a site for an important international southern observatory is transcendent. It should be done with much deliberation, and would require two or three years before satisfactory site-testing could be completed. (3) There is almost unanimous agreement that the basic equipment should consist of one large reflector (aperture between 75 and I25 inches) profusely equipped with spectroscopes at Newtonian, Cassegrainian, and Coudé foci; and one large-field Schmidt-type reflector of aperture somewhere between 30 and 60 inches, and this second instrument, which produces a high ratio of reduction time to observing time, should be built first. (4) There is no need of a solar telescope in the southern hemisphere, and little need of small cameras. (5) The southern international observatory should have a small but highly competent resident staff, and large funds to cover the expenses of visiting observers.

In the interest of the project of international observatories, I have had many conferences with astronomers, travellers, meteorologists, and, of most importance, with officials of the United Nations and U.N.E.S.C.O. The obtaining of effective sponsorship and financing may be difficult because of the extraordinary economic and political conditions of the times. But the picture should be clearer by August, when we meet in Zürich.

Some remarks on a site satisfactory for a large international observatory may be useful, as a point of departure for the discussions in Zürich.

Since large telescopes, with appropriate mechanical and electronic shops, require a considerable staff in residence, in addition to visting astronomers, the living comforts must be given some consideration. The observatory could not work satisfactorily if it is too severely isolated (as in central Australia, for example). It should be in a region free of the Aurora Australis and as accessible as possible (other things being equal) by train or plane. Almost certainly the site must be found in South Africa or in South America. Preferably the latitude should be between $-10^{\circ}$ and $-35^{\circ}$; the altitude between 6000 and I0,000 feet; the clear nights not less than 225 per year, with no two-month period on the average more than $50 \%$ cloudy; and the seeing of highest possible quality.

These conditions are very difficult to meet, but northern Chile, north-west Argentina, 
the Bolivian plateau, possibly Southern Peru should be investigated in South America, and in South Africa consideration should be given to the Windhoek and Mount Brukkaros regions in south-west Africa, and various places in Bechuanaland, Transvaal, Mozambique, Angola, and Rhodesia. To approach some of the required ideals for a site, others must be compromised. For their very exacting work on the Sun, the observers of the Smithsonian Astrophysical Observatory have found Montezuma in Northern Chile the most satisfactory, and in south-west Africa worked successfully at Mount Brukkaros for several years. Dr L. B. Aldrich, Director of the Smithsonian Astrophysical Observatory, and Dr J. S. Paraskevopoulos merit membership on Commission 39.

At this stage of the development of the project, it would seem to me advisable to seek a grant of some $\$ 50,000$ for a two-year investigation of astronomical sites. Such a survey, if properly planned and executed, could bring to astronomers and others very useful information about observing conditions throughout the southern hemisphere, even if the studies were not immediately followed by the establishment of a southern observatory. Careful study of existing meteorological and physiographic records would go a long way in limiting the regions that should be carefully examined. If the whole of the grant of $\$ 50,000$ is not necessary, the remainder could be devoted to detailing the plans for telescopes, accessories, and buildings.

Dr Gaviola writes that two I2-inch $f / I_{5}$ Cassegrain reflectors could be built in Córdoba, if desired, under his supervision at a cost of about $\$ 1000$ each; and he estimates that the total cost of building and using these instruments throughout the year would be about \$12,000 ('experienced observers available').

But the problem of selecting a site, and testing the conditions, is so serious that a special sub-committee should be selected for the purpose of analysing methods and planning procedure.

HARLOW SHAPLEY

President of the Commission

\section{Compte rendu de séance}

Président: M. H. Shapley.

Secrétaire: M. D. Chalonge.

Le Président fait d'abord un exposé général, développant les raisons qui militent en faveur de la création d'institutions astronomiques internationales. Cet exposé est résumé dans les paragraphes I et II, la discussion dans le paragraphe III et les voeux de la Commission dans le paragraphe IV de ce rapport.

\section{INTRODUCTION}

La création d'institutions astronomiques de recherche ayant un caractère international semble s'imposer pour diverses raisons.

La première résulte de la répartition très irrégulière des grands observatoires modernes à la surface du globe: certains pays, notamment en Europe, en sont complètement privés mais il ne serait ni possible, ni même désirable de pourvoir chaque pays d'un tel établissement qui côute fort cher et qui ne pourrait vraisemblablement pas toujours être utilisé à plein rendement par les seuls astronomes de ce pays.

Il serait plus avantageux à tous points de vue, et surtout eu égard aux extraordinaires conditions économiques du moment, de créer un petit nombre de centres de travail astronomique munis des instruments les plus modernes et dont l'utilisation serait permanente: les astronomes des pays défavorisés par leur équipement pourraient ainsi se procurer les données d'observations et les documents qui leur sont nécessaires.

Cette proposition a déjà été faite sous une forme plus ou moins générale par divers pays: lors de la réunion du Comité Exécutif de l'U.A.I. à Copenhague, en I946, la Pologne 
a proposé la création d'un observatoire international et, tout récemment, la délégation française au Comité Economique et Social réuni à Genève, a demandé de mettre sérieusement à l'étude le projet de création de laboratoires de recherches internationaux pour les sciences fondamentales. (Voir dans l'appendice de ce rapport.)

L'existence de foyers permanents de rencontre et de collaboration scientifique internationale aurait par elle même une grande valeur et serait sans nul doute une source féconde de travaux.

Enfin il ne faut pas perdre de vue que la coopération scientifique entre les divers pays, que ces établissements contribueraient à développer, constitue un aspect particulièrement important des relations internationales.

\section{Propositions}

Pour mettre en œuvre les idées générales qui viennent d'être énoncées, H. Shapley fait les trois propositions ci-dessous:

(I) Un Observatoire Astronomique International devrait être créé dans les conditions qui ont été définies dans son rapport, en tenant compte des suggestions faites par divers astronomes (voir, dans l'appendice, un résumé de ces suggestions) : cet observatoire devrait être édifié dans l'hémisphère austral, de préférence entre - $10^{\circ}$ et $-40^{\circ}$ de latitude dans un site choisi avec soin en tenant compte non seulement des qualités de l'atmosphère et du climat, mais des conditions d'accès et d'habitabilité, car le personnel permanent d'astronomes et de techniciens s'accommoderait difficilement de conditions d'isolement trop sévères.

Les éléments principaux de son équipement seraient un grand réflecteur (de 75 à I25 pouces) muni de nombreux spectrographes et un réflecteur de Schmidt, à grand champ, de 30 à 60 pouces de diamètre. Aucun équipement solaire ne serait nécessaire.

(2) Un centre ou Laboratoire Astronomique International devrait être édifié, de préférence dans un petit pays d'Europe, comme la Suisse, le Danemark, la Norvège. Cet établissement devrait comprendre des laboratoires munis du matériel le plus perfectionné (spectrographes, photomètres, microphotomètres, etc.), des ateliers pour la construction et la mise au point d'appareils spéciaux, des bureaux de calculs équipés des machines les plus modernes, une bibliothèque internationale.

Des documents (photographiques, spectroscopiques et autres) obtenus dans un groupe de grands observatoires des divers pays, seraient en outre mis à la disposition des personnes fréquentant ce Centre qui serait accessible à tous les astronomes. Il faut en effet noter que beaucoup de documents astronomiques peuvent être étudiés très loin des instruments qui ont servi à les obtenir.

Un tel centre pourrait, à relativement peu de frais, être créé, équipé et mis en fonctionnement dans un laps de temps relativement très court. (Voir, dans l'appendice, le rapport de $\mathrm{H}$. Shapley, concernant le projet pour la création d'un laboratoire international pour la recherche astronomique.)

(3) Pour rendre possible aux astronomes le séjour dans l'un des deux établissements internationaux dont il vient d'être question, ainsi d'ailleurs que dans les grands observatoires nationaux ouverts aux étrangers, un Fonds International de Voyages devrait être créé: il permettrait de couvrir les frais de voyage et de séjour quand ce serait nécessaire.

\section{Discussions}

F. Becker a été pendant trois ans membre d'une mission astronomique à La Paz en Bolivie. Il considère que $\mathrm{La} \mathrm{Paz}$ remplirait les conditions demandées pour l'édification d'un grand observatoire austral: Latitude $-16^{\circ}$, grande altitude (près de $4000 \mathrm{~m}$.) ressources d'une grande ville. Il pourra fournir d'autres informations si cela est nécessaire.

$H$. Shapley pense que, du point de vue purement astronomique, la Station de Montezuma (Nord du Chili), qu'ont utilisée longtemps les observateurs du Smithsonian Astro- 
physical Observatory of Washington, serait tout à fait excellente. Mais elle ne remplirait pas les conditions humaines car elle se trouve dans une région désertique. Il faudrait examiner les possibilités présentées par le Sud Ouest Africain (Transvaal, Rhodésie, Bechuanaland): les astronomes du Smithsonian Observatory ont travaillé avec succès pendant plusieurs années au Mount Brukkaros.

Bourgeois signale que l'I.R.S.A.C. (Institut de Recherches Scientifiques en Afrique Centrale) s'occupe depuis l'an dernier d'organiser au Congo Belge des Centres de Recherches qui seraient ouverts aux chercheurs des différentes disciplines et des divers pays. Une expédition a été envoyée il y a quelques mois au Congo Belge pour chercher un emplacement favorable pour un observatoire de haute altitude. Il faut un endroit élevé, situé au-dessus de la zône des précipitations, éloigné des volcans (fumées) et des tremblements de terre, assez proche cependant de régions habitées. Ces diverses conditions définissent un plateau situé à $3000 \mathrm{~m}$. d'altitude, aux environs de $-6^{\circ}$, entre le lac Kivu et le Tanganyika. Ce plateau est dominé par des montagnes plus élevées.

Les premières recherches ont commencé il y a quelques semaines sur un sommet de $3500 \mathrm{~m}$. Le capuchon de nuages n'a permis le travail d'observation que pendant cinq nuits dont trois étaient très bonnes et présentaient une faible turbulence. D'autres lieux, moins humides, ont été et seront explorés en d'autres saisons.

Woolley signale qu'en Australie l'influence des aurores australes doit être négligeable.

G. Abetti mentionne une autre activité possible pour le laboratoire astronomique International: il pourrait être chargé de rassembler dans un délai aussi bref que possible toutes les informations concernant l'activité solaire, et aussi celles relatives aux comètes, novae, etc. - - et de les diffuser.

Federer suggère que le laboratoire astronomique international soit installé, au moins partiellement, sans faire intervenir l'U.N.E.S.C.O., ceci afin d'éviter les retards administratifs et pour gagner du temps.

$H$. Shapley objecte à cette proposition qu'il semble au contraire très désirable que les établissements projetés apparaissent comme l'œuvre collective des nations membres de l'U.N.E.S.C.O.

$O$. Struve remarque que toutes les activités ne pourraient se manifester avec la même facilité dans le laboratoire astronomique international: il est parfois très difficile, selon lui, d'étudier les résultats des observations loin de ceux qui les ont faites.

$H$. Shapley répond que c'est une question d'espèce et que de nombreux travaux resteraient possible dans le laboratoire international: par ex. le long travail de dépouillement des clichés fournis par un télescope de Schmidt, ou l'analyse de spectres de grande dispersion obtenus à l'aide de grands télescopes pourraient très bien être confiés à des astronomes travaillant dans ce laboratoire astronomique international.

$O$. Struve se place à un point de vue assez différent de celui de $\mathrm{H}$. Shapley. Alors que ce dernier accumule des documents aussi nombreux que possible en vue de travaux généraux, O. Struve s'intéresse à des recherches plus spécialisées qui exigent que les documents à analyser soient pris et calibrés en fonction de chaque recherche particulière.

$R$. E. Wilson approuve la création de l'observatoire et du laboratoire international. L'Observatoire du Mont Wilson a depuis longtemps une activité semblable à celle que devraient avoir ces établissements: des astronomes étrangers peuvent venir y travailler, des observations sont faites pour eux et des documents pourraient être envoyés au laboratoire international.

Woolley signale que dans l'hémisphère sud on manque d'astronomes et de techniciens mais que l'on a suffisamment de télescopes. Aussi le laboratoire astronomique international lui semble-t-il plus important que l'observatoire international proposé dans l'hémisphère austral.

Th. Dunham pense que le laboratoire international serait très désirable, mais qu'il devrait être spécialisé dans diverses directions. Il devrait comprendre, entre autres, un laboratoire d'essais photographiques, un laboratoire de recherches optiques, un laboratoire destiné au perfectionnement d'instruments de mesure existants et à la mise au point d'instruments nouveaux, etc. 
O. Struve, appuyant une proposition contenue dans le projet de H. Shapley, pense qu'une des grandes machines à calculer modernes devrait être l'un des premiers éléments du laboratoire international.

Owren, appuyant la troisième proposition de H. Shapley, demande des fonds pour faciliter l'échange des astronomes entre les observatoires et instituts existants.

Lindblad approuve dans leurs grandes lignes les plans proposés et estime que la question financière sera la plus importante à résoudre.

Chalonge attire l'attention sur la Station Internationale du Jungfraujoch qui est, en petit, une réalisation du même type que celles que demande la Commission 39 et qui fonctionne avec grand succès depuis plusieurs années. Elle a été créée par la collaboration de divers pays, la Suisse (dont l'apport est le principal), la France, la Grande Bretagne, la Belgique, l'Allemagne et l'Autriche.

\section{VEuX de LA Commission}

A la suite de ces échanges de vue le président de la Commission remercie les personnes qui ont pris part à la discussion et demande si l'activité de la Commission 39 doit se poursuivre: un oui unanime lui répond. La création d'un observatoire astronomique international et d'un laboratoire astronomique international pourvus d'équipements modernes est demandée par la Commission. Il semble prématuré de demander dès maintenant la création d'un fonds international pour l'échange des astronomes, étant donné que pour l'instant, un comité pour cet échange est en fonctionnement avec l'appui matériel de l'U.N.E.S.C.O.

Stratton suggère que l'on adjoigne à la Commission 39 les personnes qui choisissent les emplacements possibles d'observatoires, ainsi que tous ceux qui ont envoyé des rapports. Il estime également désirable d'inclure dans la commission des personnes qualifiées pour juger des problèmes qui sont indiqués pour être analysés avec de grandes machines à calculer modernes.

\section{APPENDIX I}

\section{Excerpts from letters relative to INTERNATIONAL ASTRONOMICAL OBSERVATORIES and LABORATORIES}

\section{Henri Laugier, Assistant Secretary-General of the United Nations:}

It was a real pleasure for me to learn that a further step has been taken by your Union to achieve international scientific co-operation.... Calling special conferences of experts and having exploration studies made by outstanding scientists are both necessary and useful for the preliminary report.

The establishment of International Research Institutions is a problem of long-range character. The preparations should consider both the moral as well as the technical aspects... .

\section{Bertil Lindblad, Stockholm Observatory:}

The question of the International Observatory interests me profoundly.... The question is a difficult one, but should mean an immense addition to astronomical activity if well handled, as I have no doubt it can be under the auspices of the I.A.U. and with the active help of those who have the greatest experience in this field, in the first hand the leading American astronomers...

The matter is of such great importance that it is much to be desired that preliminaries for site selection and instrument planning can be started at an early date. Regarding the instrumentation I agree in the main with your own list. Careful exploration should of course include tests for seeing, which can be made with fairly small telescopes, but has to extend over a considerable time. I suppose three or four separate expeditions would have to be active simultaneously on this problem. As each expedition would be quite small, the expenses would 
not be considerable. Most of it would be travel expenses for the members of these expeditions. These may perhaps be partly recruited from observatories most closely situated to the regions to be investigated. For my own part I most heartily endorse your proposal to ask the Social and Economic Council of U.N.E.S.C.O. for a fund to cover expenses of site selection and instrument planning....

\section{S. Bowen and Walter Baade, Mount Wilson Observatory:}

It is the opinion of our group that the International Astronomical Union would be justified in asking for international support for an astronomical observatory only in case this observatory is planned to produce the maximum return in effective astronomical results. Even from the standpoint of international co-operation and good will we believe this is necessary....

The following comments on the proposed plans for the observatory, and the instrumentation that it is desirable to provide for the observatory, are based on the above assumption as to the fundamental principle that should govern the plans for the observatory:

(I) We agree thoroughly with your proposal that such an observatory should be located in the Southern Hemisphere.

(2) It is our opinion that the instrumentation of such an observatory should be limited to a large reflector of 80 to 120 inches aperture and to a large Schmidt camera for survey purposes. Our reasons for questioning the other items on the proposed list are as follows:

In general, there is no appreciable advantage in locating a coronagraph in the Southern Hemisphere over much more convenient regions in the Northern Hemisphere. In any case, the altitude requirements for such a coronagraph station are such as to preclude its location at the same station that would be suitable for stellar instruments. Furthermore, many of the investigations that should be carried out by a coronagraph involve systematic observations over an extended period of years. This type of investigation is obviously not suited to a staff whose personnel is made up largely of visitors that are changing at relatively short intervals. In other words, such a coronagraph would be much more effective if it were built in the Northern Hemisphere and provided with a permanent resident staff. There is therefore no great argument for such a station being undertaken as an international project.

The same reasons hold for the elimination of the equipment for the study of the ionosphere and related phenomena. Similarly, small cameras for patrol purposes and for the study of meteors, and so forth, should also be eliminated from the programme. These again are most effective when operated by a permanent staff. Furthermore, they are relatively inexpensive and are just the type of equipment that the small observatories in small countries should and can provide for their own staff.

Probably the most extensive study of the question of site that has ever been made was carried out by the 200 -inch project. The preliminary studies were made with the aid of about ten 4-inch telescopes on stationary mounts. These were provided with high-power eyepieces and were permanently mounted to observe Polaris. A few months' observations were made at each of some two or three dozen sites. The small number of sites selected by this preliminary survey were then studied in more detail with the use of two r2-inch Cassegrain reflectors having equatorial mounts. This equipment at the present time would probably cost about $\$ 10,000$. In addition, some five or ten man years of time would be required for the observations. It was found, however, in the 200 -inch tests that relatively young and inexperienced men could be trained to take these observations.

The permanent staff of such an international observatory should be kept small and the major part of the observations should be handled by the visiting astronomers. However, we believe it would be necessary to have a small permanent staff of one astronomer in each of about three fields. This small group would be necessary to maintain and design auxiliary equipment, to provide instruction in the use of equipment and in the planning of effective programmes with these large instruments, and to give continuity to the work of the observatory....

[Several members of the Commission wrote similarly with regard to General Policy, Site Selection, Equipment, and Staff. H. S.] 


\section{Sir Harold Spencer Jones, Royal Observatory, England:}

There are two alternative possibilities for the scope of an International Observatory. In the first place, it could be primarily an institution where qualified astronomers from observatories in other countries could come to secure observational data which are not obtainable in their own country, either, because of lack of suitable instrumental equipment or because of difference in latitude or other reasons; the observational material would be taken back by the visiting astronomers to their own observatories and worked up there. For this purpose it would be advantageous that the programmes of observations should be of a type that require a large ratio of time spent in measurement and reduction to time spent in observations. It is desirable, however, that each observer should plan his own programme, secure his own plates, standardize and develop them himself, etc. It is not in general conducive to the best quality of material and the highest accuracy if the plates are obtained by resident staff and sent to various observatories. If the observatory is restricted to this sort of use, it would not need a large resident staff of trained astronomers, but a well-qualified astronomer with one or two assistants would be needed.

Secondly, the scope of the Observatory might be extended to permit of research students undertaking work there. Their supervision and guidance would necessitate a considerably larger astronomical staff. In my opinion, it is undesirable that the international observatory should cater for anyone with a status inferior to the advanced research graduate, who should be competent to work at the Observatory without detailed guidance... .

Resident Staff. As a minimum staff I suggest a Director who should be a trained practical astronomer of some eminence with initiative, energy, and authority, but not too old; two scientific assistants; four mechanic night-assistants, who would be responsible for supervising the use of the telescopes by night, and for their maintenance (cleaning, oiling, testing, etc.) by day; day and night duties should be alternated. There should also be a secretary, who would be generally responsible for the business details, an assistant secretary, three or four typists, and a small workshop staff....

Summing up, I am in favour of the International Observatory not being started on too ambitious a scale and would favour in the first instance an equipment consisting of one or two Schmidt cameras (or alternative designs) and a large Newtonian reflector.

The programmes to be primarily of a type in which the ratio of time for working up the results is large in relation to observing time.

The astronomical staff of the observatory to be small. Advanced research graduate to be the minimum qualification for use of the equipment.

By starting on fairly modest lines, development is not excluded but the lines along which the development should proceed will be guided by the experiences gained.

\section{G. A. Shajn, Simeis Observatory, U.S.S.R.:}

It appears quite natural that the proposed International Observatory should be situated near or rather south of the equator, to balance at least partly the uneven opportunities for the study of the Southern Hemisphere as compared with the Northern one.

It is desirable that the new observatory should not be confined to conventional lines and routine way of using big telescopes. The great changes in optics and electronics (radiophysics, radio-astronomy) in the last decade should be carefully considered, since they could enormously increase the effectiveness of the telescopes....

From the very first the designing of the big telescope should be made in line with new trends, both in the instrumental technics and in the scientific tasks. In the light of this it may not be so urgent to have a reflecting telescope much surpassing $80-90$ inches in size. In that case the building of such an instrument will become more realizable.

For many fundamental problems of stellar statistics the new-type telescopes of the size $4^{0}-5^{\circ}$ inches (maybe of Baker-Schmidt or Maksutov type), supplied in addition with transmission grating or prism, will be a most effective instrument for many years.

A careful study of the conditions for good seeing is required. Particularly it is necessary to check Lyot's results concerning the influence of closed, skeleton, or open type of tube on the images.... 


\section{Joseph Witkoweski, University Observatory, Poznań, Poland:}

I see from your letter that the two-hemisphere plan has been reduced to a Southern Observatory. The arguments for such a compression of the original project are valid only to a certain degree, and my personal opinion is that the experience of the future International Southern Observatory will be favourable for the foundation of a Northern Observatory. The twohemisphere plan is certainly the one preferred by every astronomer as 'no matter what his country, he would be quite free to make use of the facilities available without any feeling of trespassing upon the welcome of the astronomers of the host country'. (Nat. Sci. Document 24, par. 2I.)

I think besides that observing stations do not solve by themselves the problem of International Observatories. Remains the important question of

(I) Central Astronomical Library.

(2) Astrophysical Laboratory.

(3) Computing Department with modern calculating machinery equipment. A modern calculating equipment is of special importance, as none of the smaller countries can afford it.

(4) Department for the study of international astronomical projects.

(5) Central Bureau of Astronomical Telegrams.

(6) Instrument and Optical Shops for building of new instruments and modifying them as experience suggests.

(7) Borrowing Section for astronomical instruments.

All these sections could be located at the permanent seat of the Bureau of the International Astronomical Union. This seat should necessarily be chosen in a place having all the facilities of communication, modern civilization and highly developed techniques, e.g. U.S.A., England, France, Switzerland....

\section{B. Lyot, the Observatory, Paris:}

Exploration d'un site-Observatoire stellaire.

Pour l'étude de la qualité des images, plusieurs méthodes pourraient être employées simultanément, mais il serait bon que les différents sites soient examinés avec les mêmes méthodes et des appareils standard, pour obtenir des résultats comparables.

La méthode décrite par Danjon et Couder, dans leur ouvrage Lunettes et télescopes, p. 9I, a l'avantage d'être visuelle, sensible et d'utiliser des observations faites à diverses hauteurs, dans différents azimuths, elle nécessite seulement un réfracteur court, de $\mathrm{I}_{5}$ à $20 \mathrm{~cm}$. d'ouverture, monté sur un pied très stable et muni de forts grossissements. Cette méthode mesure principalement la courbure des ondes atmosphériques.

On pourrait employer, en même temps, une méthode qui mesure l'amplitude des réfractions accidentelles, telle que des trainées photographiques d'étoiles ou le dispositif visuel employé à Mount Wilson et Mount Palomar, ce dernier est d'un emploi plus commode, mais moins sensible.

Il serait bon d'enregistrer aussi les variations de la température, de l'humidité et la nébulosité.

Les sites vraisemblablement les meilleurs et, par conséquent, les plus intéressants à explorer, pourraient être choisis d'aprés certaines conditions locales:

A l'altitude la plus grande qui permette un accès et des conditions de vie assez faciles, sur un sommet isolé de préférence à un plateau et surtout à un col. Sur les plateaux, l'influence du sol refroidi par le rayonnement nocturne est beaucoup plus grande que sur les sommets, ainsi que la variation diurne de température. Au-dessus des cols, l'air est violemment perturbé par des courants ascendants, des tourbillons et la différence de température entre les deux versants.

La proximité de la mer peut être favorable, au moins en été, les vents froids à basse altitude, venant de large s'opposant aux courants ascendants (Lick Observatory).

Des îles peu étendues et possédant des sommets assez élevés, comme les Açores seraient à examiner; certaines îles, même de faible altitude, seraient à considérer, lorsque la variation diurne de température y est très faible, comme à Ceylon.... 


\section{Otto Struve, Yerkes Observatory:}

The permanent staff of the International Observatory should be small. I suppose that the principal purpose of the project is to provide facilities for observing to astronomers in those countries where there are no large observatories. I want to call attention to the great danger which would arise if American, English, French, and Swedish astronomers should fail to take an active participation in the operation of the new institution. Astronomers who have not had experience in handling large telescopes would probably be inefficient and unproductive. Hence, it would be desirable to have a thoroughly competent observational astronomer act as superintendent even though this person might not especially require the facilities offered by the institution. I am sure the representatives of the smaller countries will understand this point....

\section{E. Gaviola, Córdoba Observatory:}

Our limited experience with seeing in Córdoba, La Plata, Montevideo, Santiago, and Chaco points to the advantage of studying seeing in the north-western part of Argentina, the Bolivian plateau-I2,000 feet high, with valleys at 9000 feet or less-the northern part of Chile, and the western part of Peru. The Smithsonian Institution has gathered experience about northern Chile, where it has one of the best solar stations (Montezuma).

I consider it advisable to send two observers equipped each with a 12 -inch $f / \mathrm{I}_{5}$ Cassegrain reflector to make simultaneous observations at points in the regions mentioned. The value of the observations would be increased by the ones already being made at Cordoba and Santiago.

The reflectors could be built at Córdoba, if desired-by a private firm-under my supervision; they would cost about rooo dollars each.

Experienced observers are available. An observer could be paid 3600 dollars a year-all expenses included.

The site-testing would cost then-with two observers-2000 for equipment plus 7200 a year for salaries and expenses plus 2800 a year for supervision: 12,000 dollars the first year.

The resident staff needs to include an astronomer or physicist capable of aluminizing or silvering the mirrors, designing auxiliary equipment, and directing its construction in the observatory's shops, keeping the auxiliary equipment up to date, etc. On the ability of this man would depend the success or failure of the attempted work of the visiting astronomers.

Small but good mechanical and optical shops with capable workers are essential. Two mechanical assistants and one optical are indispensable. A business manager, one secretary, night assistants (two per large instrument), one cook, several peons and servants would complete the permanent staff...

\section{B. Aldrich, Smithsonian Astrophysical Observatory:}

Brukkaros in South-west Africa is none too good for night work because haze, clouds, and wind are too prevalent...

If our staff at Montezuma can help by making special night observations suitable to your purpose, please let us know.

\section{Waldmeier, Zürich Observatory:}

It seems to me of the greatest importance to discuss and to clear up, what kind of work is to be done at the international observatories in question, especially if it is to be routine work (in this case the instruments would be needed for the daily observations) or if the observatories should be reserved for certain researches of short period. It depends on this question, what sort of instruments we have to choose... .

\section{R. O. Redman, Cambridge Observatories:}

Should we not try to outline in a general way, but not too vaguely, the programmes of observation which are likely to be attempted, and then try to provide instruments for these? It seems impossible to cater for every need. Perhaps it would be wise to envisage an observatory 
beginning with only a small nucleus of instruments, but with opportunity to add to these at rather frequent intervals, when the need appears sufficiently urgent....

Resident staff. Yes, but plenty of technical knowledge should be available at the observatory. Many would-be observational astronomers are lamentably ignorant of the general 'know-how' of practical astronomy, or at least have been in the past. Much of this cannot be learned from books, and the technical staff would have to be prepared to cope with the weaker brethren as well as with observers of the very first rank.

Difficulties might arise with a multi-national resident staff, especially if the observatory were rather isolated. From this point of view it would be highly desirable to provide easy and frequent transport to the nearest large centre of population. This argues against any very remote site. Most of the maintenance staff would presumably be recruited locally. A good superintendent might need to be an exceptionally gifted man, humanly as well as astronomically....

\section{APPENDIX II}

\section{Proposal FOR AN INTERNATIONAI LABORATORY FOR ASTRONOMICAL RESEARCH}

While a special Commission of the International Astronomical Union is considering the plan for a large international observatory with powerful telescopic equipment, it would seem appropriate to consider also the establishment in Europe of specially equipped laboratories for astronomical and astrophysical research, which could soon be available to the astronomers of many countries and very effectively contribute to astronomical knowledge and to the development of international co-operation.

The committee on the location and equipping of an international observatory, that would be owned and operated by the astronomers of all countries, has preliminarily decided, for excellent reasons, that the international observatory should be in the Southern Hemisphere, probably in South Africa or South America. The examination of potential sites for such an important observatory would require at least 2 or 3 years, during which all relevant astronomical and meteorological factors could be thoroughly investigated.

Although the international telescopes should be in the south, there is no need that all new international astronomical researches should be transferred to the Southern Hemisphere. The majority of astronomical researches are now best carried on away from the telescopes. That is, thanks to astrophotography, the detailed investigations of stars, stellar spectra, nebulae and galaxies are taken from the telescopes to the laboratories and measuring rooms of the astronomers. The situation is somewhat analogous to the researches of the botanist, who deals frequently with materials collected by others, or assembled by professional collectors who themselves are not prepared to carry on taxonomic or morphological studies.

It would be possible to assemble in a central laboratory both a good working library and the computing machinery, measuring engines, laboratory photometers, and microdensitometers that would make the analysis of astrophotographs fully as efficient as such analyses can be when made in the observatories where the photographs are exposed. If in this fully equipped astronomical laboratory we should make ample provision for a small resident staff, and for visiting scientists, and further an arrangement whereby photographic material covering many fields of astronomy is supplied in abundance, we could rapidly set up one of the most important astronomical centres of the world.

A basic requirement for the proposed international laboratory would be a plan whereby significant material for measurement, analysis, and discussion could be provided. Relying on the traditional co-operative spirit of astronomers, and the traditional hospitality of the great observatories, I suggest that we already have in existence an exceedingly effective international research institution. The most powerful and expensive part of an international astronomical institution already exists in the widely scattered large observatories. 
I propose, therefore, that if the United Nations will endorse and provisionally finance the plan, we form, as a preliminary and basic part of the proposed international laboratory, an Association of Contributing Observatories. Perhaps ten of the active observatories now existing, in addition eventually to the proposed southern international observatory, could be counted in this plan. One naturally lists as sources of astronomical raw material three of the Harvard observatories - namely, the coronagraphic station in the Rocky Mountains, the southern station at Bloemfontein, the northern station at Oak Ridgein addition to the collection of about half a million astrophotographic plates in Cambridge. Other American, South African, and European observatories could doubtless provide existing material, or better, provide by arrangement new series of astrophotographs for special projects. Presumably an appropriate budget would be available in the set-up of the International Laboratory to cover the expenses of photographic materials, telescope operations, shipping, and insurance. Expert and experienced supervision would be required to handle the many minor complications as well as guide the general policy. A committee of the I.A.U. should act as Board of Directors.

The question might be raised as to whether it would not be simpler to provide large travelling fellowship funds so that individual astronomers could be resident at selected observatories. Such a project is also good, but is quite different from the plan here sketched. The American observatories, for instance, are already crowded and cannot freely welcome unlimited visitations. A valuable telescope can often be more safely and efficiently handled by professional operators than by casual and inexperienced visitors. The peculiar advantages of assembling at a central laboratory the research astronomers from various countries and with various problems are not realized by the guest traveller, who himself has only the rights of a temporary visitor, and not the vested interest and responsibility of a participating owner of an international enterprise.

The plan I am exploring could be set up promptly. It should be situated, I would suggest, in one of the smaller European countries-Norway, Denmark, or Switzerlandeasily and inexpensively available to the majority of the countries of the world in which astronomical research is carried on. In a year's time, if suitable quarters could be found, an international laboratory could be outfitted with some effective measuring machinery, a working library, a managerial establishment, and with thousands of astrophotographs suitable for research and as yet not studied. And in three years' time, a fully established astronomical laboratory could be in operation.

To begin with, no extensive telescopic equipment for observational work is recommended, but perhaps a few simple or special instruments that make no high demands on climatic conditions would not be inappropriate. When fully established, the International Laboratory should have spectroscopic, photographic, and possibly optic laboratories. There might be some laboratory equipment appropriate for the exploration of those borderline fields between astronomy and other sciences. Unquestionably the fully equipped laboratory should have one of the great modern digital calculators, ${ }^{*}$ in addition to smaller calculating machinery, because this institution would also naturally be the headquarters for large endeavours in celestial mechanics, and possibly for the astrophysical work that gains through team work and the use of the utmost in calculational aids.

The proposed International Laboratory might naturally be the headquarters for international activities in astronomy-the place where some of the international ephemerides are prepared or published, the headquarters for bibliographies and special card catalogues, and possibly the home of the International Astronomical Union.

Naturally the study of the problem of developing an international astronomical laboratory should be the function of a special committee of the International Astronomical Union. A liaison committee serving the International Astronomical Union and U.N.E.S.C.O. and other United Nations sub-organizations would be appropriate. It should

* At the Zürich meeting it was generally agreed by Commission 39 that the proposed Central Astronomical Laboratory could and probably should be started with an all-science United Nations Computational Laboratory. 
not be difficult to work out an initial budget for equipment, for buildings, and for annual operations as soon as the magnitude of the effort is tentatively decided upon. Whether this be only a small enterprise, or be one of moderate size, or one that aims to develop into the most important astronomical institution in the world-in any form its establishment would serve a useful purpose in science and in international relations. The returns will be proportional to the amount of time, spirit, and money invested, and the leadership which astronomers could provide through this activity might be of inestimable value in the promotion of the international co-operation that will be necessary if our immediate posterity is to have the privilege and honour of doing astronomical research. 